\title{
ANALISIS KUALITAS AIR SUNGAI YANG BERMUARA DI PERAIRAN TELUK KAO HALMAHERA UTARA
}

\author{
Azis Husen* \\ Staf Pengajar FAPERTA UMMU-Ternate, Email: azishusen50@yahoo.com
}

\begin{abstract}
ABSTRAK
Penelitian ini bertujuan menganalisis dan menentukan tingkat pencemaran merkuri $(\mathrm{Hg})$ di perairan Teluk Kao Halmahera Utara. Metode yang digunakan adalah metode survei observasi wawancara dan pengambilan sampel air dengan cara purposive sampiling sedangkan untuk analisis air dan sedimen mengunakan alat spektrofotometer penyerap atom (atomic absorption spectrophotometer, AAS). Analisis kualitas air sungai, air laut di perairan Teluk Kao Halmahera Utara untuk pagi dan sore dengan nilai sebesar $0,004 \mathrm{mg} / \mathrm{L}$ $0,0038 \mathrm{mg} / \mathrm{L}$. Sedangkan kandungan merkuri $(\mathrm{Hg})$ untuk sedimen pagi dan sore dengan nilai 0,0032, mg/L - 0,0076 mg/L. Berdasarkan dari hasil tersebut bahwah mutu air sungai Kobok dan Taolas di perairan Teluk Kao Halmahera Utara sudah tidak bisa dikonsumsi sesuai Peraturan Pemerintah Pengelolaan air minum secara konvensional (kelas 1), 0,001 ppm, (kelas 2 dan 3), 0,002 ppm dan (kelas 4). 0,005 ppm dengan demikian mutu air sungai Teluk Kao sudah tidak aman untuk di konsumsi bagi masyarakat Teluk Kao. Sedangkan untuk sedimen sungai Kobok dan Taolas Teluk Kao sudah tidak lagi memenuhi Standar Bahan Baku Mutu sesuai Peraturan Pemerintah No. 82 Tahun 200 kelas I. 0,001 mg/L kelas II. 0,002 mg/L kelas III. 0,002 mg/L kelas IV 0,005 mg/L.
\end{abstract}

Kata Kunci : Pencemaran; merkuri (Hg);air sungai; air laut; sedimen

\section{PENDAHULUAN}

Teluk Kao memiliki karkateristik tersendiri karena keunikan bentuk teluk seperti kantung dengan diameter teluk 15 km2. Teluk kao berada di lima wilayah kecamatan, yaitu Kecamatan Malifut, Teluk Kao, Kao Raya, Kao Barat, dan Kecamatan Kao Utara, perbatasan dengan Kabupaten Halmahera Timur dan Kabupaten Halmahera Barat (BPS Halmahera Utara, 2013).Logam berat yang bersifat toksik maupun esensial terlarut dalam air dan mencemari air tawar maupun air laut. Sumber pencemaran ini banyak berasal dari pertambangan, peleburan logam dan jenis industri lainnya, dan juga dapat berasal dari lahan pertanian yang menggunakan pupuk atau anti hama yang mengandung logam Darmono, (2001).

Pencemaran suatu perairan oleh logam berat, telah banyak dikembangkan pemantauan secara kimia, dengan menentukan kadar setiap zat pencemar pada air ataupun sedimen Darmono, (2008). Penyebab pencemaran perairan antara lain karena penggunaan bahan bakar fosil, limbah industri, buangan limbah domestik, pemakaian pestisida dan pertambangan. Hasil analisis merkuri $\mathrm{Hg}$ oleh Badan Lingkungan Hidup Halmahera Utara, (2012) di sungai Bora Teluk Kao mendapatkan kandungan merkuri pada air sungai sebesar $0,00005 \mathrm{mg} / \mathrm{L}$. Sedangkan hasil penelitian Hamid (2011), air laut perairan Dum-Dum mendapatkan beban merkuri $(\mathrm{Hg})$ sebanyak 0,0004-0,0007 ppm. Berdasarkan Standar Nasional Indonesia (SNI) 2009 tentang batas maksimum cemaran logam berat dalam pangan adalah $0.05 \mathrm{mg}$. Hal ini berarti bahwa kandungan $\mathrm{Hg}$ di perairan Teluk Kao masih di bawah nilai ambang batas. namun demikian, apabila usaha penambangan emas tidak mengolah limbah secara baik, maka kandungan Merekuri Hg di perairan Teluk Kao akan terus 
meningkat dan terakumulasi hingga melebihi

$\exists$ nilai ambang batas. Berdasarkan latar belakang diatas maka tujuan dari penelitian ini bertujuan menganalisis dan menentukan tingkat pencemaran merkuri $(\mathrm{Hg})$ di perairan Teluk Kao Halmahera Utara.

II. Metode Penelitian

Analisis kualitas air di Laboratorium Lingkungan dan Bioteknologi Perairan, Fakultas Perikanan dan Ilmu Kelautan, Universitas Brawijaya Malang. Analisis mengunakan alat spektrofotometer penyerap atom (atomic absorption spectrophotometer, AAS) untuk mengetahui kandungan logam berat merkuri $\mathrm{Hg}$ dengan larutan, HNO3, SnCl2, HgSO4, dan HCI04 di Laboratorium Perum Jasa Tirta Kota Malang.Tempat dan wadah yang terbuat dari Styrofoam untuk menyimpan sampel air, sebelum dilakukan uji laboratorium, kertas label untuk memberi tanda pada sampel, es di gunakan untuk menjaga sampel air agar tidak rusak.

Berdasarkan Standar Nasional Indonesia SNI 06-2412-1991 tentang metode pengambilan contoh kualitas air : (1) sungai dengan debit kurang dari $5 \mathrm{~m} 3 /$ detik, contoh diambil pada satu titik di tengah sungai pada 0,5 kali dengan kedalaman permukaan air; (2) sungai dengan debit antara 5-150 m3/detik, contoh diambil pada dua titik masing-masing pada jarak $1 / 3$ dan 2/3 lebar sungai yaitu 0,5 kali dengan kedalaman permukaan air; (3) sungai dengan debit lebih dari $150 \mathrm{~m} 3 /$ detik contoh diambil minimum pada enam titik masing-masing pada jarak $1 / 4,1 / 2$ dan $3 / 4$ lebar sungai yaitu 0,2 kali dan 0,8 kali kedalaman dari permukaan air. Alat untuk mengambil sampel air adalah gayung plastik bertangkai (SNI 6989.57:2008).

Lokasi pengambilan sampel air dari hulu sampai hilir sungai Kobok dan Taolas Teluk Kao. Tempat sampel merupakan jalur tempat pembuangan limbah oleh PT. Nusa Halmahera Miniral dan TambangTradisional PETI yang mengekspolitasi emas sisa limbahnya di buang pada sungai Tabobo dan sungai Taoalas kedua sungai ini akhirnya mengalir hinggake muara hilir Kobok dan hilir Taolas perairanTeluk Kao.

Pengambilan sampel menggunakan metode survei dengan melakukan observasi wawancara masyarakat dengan mengunakan perahu tradisional oleh masyarakat dan peneliti. Penentuan lokasi pengambilan sampel air dengan cara purposive sampiling. Untuk Pengambilan sampel air dilaksanakan di perairan Teluk Kao Kabupaten Halmahera Utara pada bulan Maret 2015 peta pengambilan sampel air dapat dilihat pada Gambar 1.

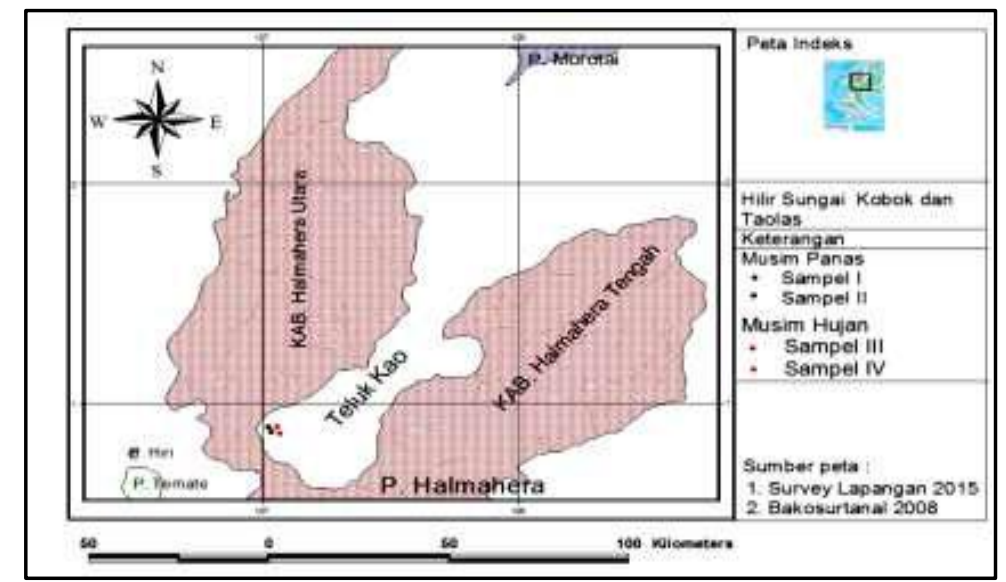

Gambar 1. Lokasi stasiun pengambilan sampel air di Perairan Teluk Kao Halmahera Utara.

III. HASIL DAN PEMBAHASAN

3.1. Parameter Fisika dan Kimia di Perairan di Perairan Teluk Kao

Pengetahuan mengenai kondisi kualitas perairan yang dicerminkan oleh nilai konsentrasi beberapa parameter kualitas air, baik secara fisika, kimia maupun secara biologi sangat diperlukan dalam merancang pengelolaan dan pengendalian pencemaran perairan tersebut. Penilaian ini pada dasarnya dilakukan dengan membandingkan nilai parameter kualitas air dari hasil pengukuran di 
lapangan dengan baku mutu perairan sesuai peruntukannya yang berlaku di Indonesia yakni mengacu pada Peraturan Pemerintah RI No. 82 tahun 2001 tentang Pengelolaan Kualitas Air dan Pengendalian Pencemaran Air. Salah satu indikator pemanfaatan perairan Teluk Kao Halmahera Utara adalah digunakan sebagai sumber air baku air minum, maka berdasarkan peraturan tersebut dalam penelitian ini sebagai pembanding digunakan baku mutu air kelas 1 yaitu air yang peruntukannya digunakan sebagai air baku air minum, dan atau peruntukan lain yang mempersyaratkan mutu air yang sama dengan kegunaan tersebut.

Berdasarkan hasil analisis pada lokasi penelitian dan laboratorium maupun pengamatan secara langsung (insitu) pada dari hulu sampai hilir sungai Kobok dan hilir Taolas masing-masing stasiun yang dilakukan dengan 2 kali ulangan pada pagi dan sore hari diperoleh nilai kualitas air yang hasilnya berbeda nyata dan tidak berbeda nyata pada setiap stasiun. Parameter yang di amati dalam penelitian ini meliputi parameter derajat suhu,salinitas, oksigen terlarut (DO) keasaman (pH), BOD (Biological Oxygen Demand), COD (Chemical Oxygen Demand), penetrasi cahaya, kesadahan, dan alkalinitas, pada sungai dan perairan laut.

3.2. Hasil Analisis Kualitas Air Secara Fisika Analisis kualitas air secara fisika dan insitu di perairan Teluk Kao meliputi antara lain yaitu: 3.2.1. Suhu

Hasil analisis pengukuran suhu air selama hasil pengamatan yang dilakukan suhu permukaan air sungai Kobok dan Taolas pada pagi hari dengan nilai suhu air sebesar $26.68{ }^{\circ} \mathrm{C}$ dan sore $26.80{ }^{\circ} \mathrm{C}$. Kisaran suhu yang mampu ditoleransi suatu biota laut yaitu berkisar 20.35 'C Rahman, (2006). Sedangkan berdasarkan baku mutu Kepmen LH No 51 tahun 2004 untuk biota laut berkisar $28.30{ }^{\circ} \mathrm{C}$. Berdasarkan hal tersebut, kisaran suhu permukaan air sungai Kobok dan Talos Teluk Kao, Kabupaten Halmahera Utara selama pengamatan masih pada kisaran normal dan dapat bertoleransi oleh biota perairan.

\subsubsection{Salinitas}

Hasil analisis salinitas perairan Teluk Kao Halmahera Utara selama pengukuran berdasarkan parameter salinitas, selama dua kali analisis pada pagi dan sore menunjukan salinitas air sungai dari hulu sungai sampai hilir Kobok dan Taolas pada pagi salinitas air sebesar 26,264 ppt dan sore salinitas air sebesar 27,311 ppt. Tingkat salinitas air sungai dan air laut perairan Teluk Kao berbeda maka secara umum pengaruh musim masih tetap berperan. Berdasarkan kisaran salinitas tersebut, perairan Teluk Kao tergolong pada perairan mixohaline, yang memiliki kisaran salinitas antara 0,1 ppt sampai 32,33 ppt (DKP Halmahera Utara, 2009).

\subsubsection{Derajat Keasaman ( $p H)$}

Hasil penelitian dan analisis derajat keasaman $(\mathrm{pH})$ di Perairan Teluk Kao Halmahera Utara menemukan setiap selama pengamatan nilai $\mathrm{pH}$ berbeda, Nilai $\mathrm{pH}$ air berbeda disebabkan sifat dari air laut yang mempunyai sistem buffer atau penyangga, sehingga mampu mengendalikan sifat asam atau basa yang masuk ke dalam perairan. Kisaran nilai derajat keasaman yang diperoleh dari hulu sampai hilir sungai Kobok dan Taolas di perairan Teluk Kao pada pagi $\mathrm{pH}$ air sebesar 8,23 dan sore sebesar 8,15.

Hasil analisis derajat keasaman perairan Teluk Kao menujukan bahwa nilai derajat keasam $(\mathrm{pH})$ dengan kadar sudah mendekati nilai di atas ambang batas, untuk perairan laut yaitu 7,0 - 8,0. Kondisi ( $\mathrm{pH}$ ) pada perairan dapat dijadikan sebagai indikator kualitas perairan. Batasan nilai pH telah ditentukan oleh Keputusan Menteri Kesehatan Republik Indonesia No. 907/MENKES/SK/VII Tahun 2002 yakni $6,5-8,5$.Nilai hasil analisis derajat keasaman $(\mathrm{pH})$

\subsubsection{Oksigen Terlarut (DO)}

Hasil penelitian dan pengukuran parameter fisika kualitas air sungai dan air laut pada stasiun pengambilan sampel kondisi oksigen terlarut dari hulu sampai hilir dari hasil analisis kualitas air secara (insitu) menujukan nilai oksigen terlarut mengalami kenaikan dan penurunan untuk pagi nilai oksigen terlarut yaitu sebesar 10,66 dan sore sebesar 10,57. Distribusi oksigen secara vertical dipengaruhi oleh gerakan air, proses kehidupan di laut dan proses kimia Achmad, 
(2006). Sedangkan menurut Salmin, (2005) perairan dapat dikategorikan sebagai perairan yang baik dan tinggkat pencemarannya rendah jika kadar oksigen terlarutnya $>5$ ppm.

\subsubsection{Penetrasi Cahaya}

Kecerahan air suatu perairan adalah dimana kondisi yang menunjukkan kemampuan cahaya untuk menembus lapisan air pada kedalaman tertentu. Pada perairan alami kecerahan sangat penting karena erat kaitannya dengan aktifitas fotosintesa. Kecerahan merupakan faktor penting bagi proses fotosintesa dan produksi primer dalam suatu perairan. Seperti diketahui fotosintesa ikan sangat membutuhkan cahaya dan apabila aktifitas fotosintesa terganggu maka akan mengakibatkan pertumbuhan ikan tidak optimal. Kecerahan air sungai dan air laut Kobok dan Taolas di perairan Teluk Kao relatif tidak normal hasil pengukuran menunjukkan bahwa kecerahan kedalaman air sungai Kobok dan Taolas pada pagi kecerahan air sungai dengan kedalaman $50 \mathrm{~cm}$ dan sore $47 \mathrm{~cm}$.

Nybakken, (1992) mengemukakan bahwa kecerahan merupakan salah satu faktor penentu dalam suatu perairan dimana proses fotosintesis masih dapat berlangsung. Banyak sedikitnya sinar matahari yang menembus kedalam perairan sangat tergantung dari kecerahan air. Semakin cerah perairan tersebut, maka semakin dalam sinar yang menembus kedalam perairan demikian sebaliknya.

3.2.6. BOD (Biological Oxygen Demand)

Hasil analisis nilai BOD (Biological Oxygen Demand) selama pengamatan di laboraturium mendapatkan nilai untuk pagi yaitu BOD air sebesar 9,60mg/L dan sore nilai BOD air sebesar $8,82 \mathrm{mg} / \mathrm{L}$.

Peningkatan nilai BOD air sungai Kobok Kao Teluk Halmahera Utara mengindikasikan bahwa semakin ke hilir kualitas air sungai semakin menurun atau telah terjadi pencemaran di bagian hilir. Faktor faktor yang mempengaruhi keberadaan COD antara lain: volume reaktor atau air, waktu tinggal padatan atau substrat, permintaan oksigen dan volume lumpur Pazstor et al., (2009).

Berdasarakan hasil analisis di Laboratorium mengatakan perairan Teluk Kao Halmahera Utara terkontaminisi limbah merkuri (Hg) yang mengakibatkan perairan tersebut tercemar. Menurut UNESCO/WHO/UNEP, (1992) Batas Maksimum BOD $_{5}$ yang diperbolehkan untuk kepentingan air minum dan kehidupan organisme akuatik adalah 3,0-6,0 mg/L. Berdasarkan Kep. Men. Negara. L.H. No. KEP-51/MENLH/10/1995 Baku Mutu Limbah Cair Untuk Industri Penyamakan Kulit. Kadar maksimum $50 \mathrm{mg} / \mathrm{L}$. Beban pencemaran maksimum 2,0 kg/ton. Kadar Maksimum $70 \mathrm{mg} / \mathrm{L}$. Beban pencemaran maksimum $2,8 \mathrm{~kg} /$ ton.

\subsubsection{COD (Chemical Oxygen Demad)}

Hasil analisis pengukuran parameter COD (Chemical Oxygen Demad) sungai Kobok dan Taolas di perairan Teluk Kao untuk pagi dengan nilai COD air sebesar 1162,64 mg/L dan sore $439,33 \mathrm{mg} / \mathrm{L}$.

Berdasarkan baku mutu air minum adalah <10 mg/l, maka perairan Teluk Kao di duga mengalami pencemaran limbah tambang Nusa Halmahera Minirals yang mengolah emas dengan menggunakan merkuri (Hg). Dengan demikian perairan Teluk Kao secara umum tidak lagi memenuhi syarat untuk digunakan sebagai sumber air minum sesuai dengan Peraturan Pemerintah No 82 Tahun 2001 Tentang Pengelolaan Kualitas Air dan Pengendalian Pencemaran Air yaitu kelas I. nilai 10 kelas II. 25 kelas III. 50 kelas IV. 100.

\subsubsection{Alkalinitas}

Berdasarkan hasil analisis di laboratorium mendapatkan nilai alkalinitas air sungai dan laut sungai Kobok dan Taolas untuk pagi dengan nilai alkalinitas air sebesar 236 $\mathrm{mg} / \mathrm{L}$ dan sore nilai alkalinitas air sebesar 200 $\mathrm{mg} / \mathrm{L}$.

Menurut Peraturan Pemerintah No. 82 tahun 2001. Perairan dengan nilai alkalinitas yang terlalu tinggi tidak terlalu disukai oleh organisme akuatik karena biasanya diikuti dengan nilai kesadahan yang tinggi atau kadar garam natrium yang tinggi.

\subsubsection{Kesadahan}

Berdasarkan hasil analisis secara kimia bahwa kesadahan air sungai dan air laut di perairan Teluk Kao pada sungai Kobok Taolas mendapatkan nilai kesadahan air untuk pagi yaitu sebesar $384 \mathrm{mg} / \mathrm{L}$ dan sore nilai kesadahan air sebesar $462 \mathrm{mg} / \mathrm{L}$.

Kesadahan air sungai dan air laut di perairan Teluk Kao masih dibawah ambang 
batas yang di tetapkan oleh Pemerintah yaitu $500 \mathrm{mg} / \mathrm{L}$ berdasarkan Peraturan Pemerintah RI No. 20 Tahun 1990 tentang Kriteria Kualitas Air serta SK. Menteri. KLH No : Kep02/MENKLH/I/1988 tentang Baku Mutu Air dan Sumber Air Golongan A dan B. yaitu kesadahan $500 \mathrm{mg} / \mathrm{L}$.

3.3. Hasil Analisis Kandungan Merkuri Hg Air Sungai dan Laut di Perairan Teluk Kao

Ada dua media sebagai indikator yaitu air, sedimen (pasir). Hasil penelitian dan analisis laboratorium di peroleh kandungan merkuri $\mathrm{Hg}$ air sungai dan laut untuk pagi 0,004 $\mathrm{mg} / \mathrm{L}$, sedangkan untuk sore sebesar 0,0038 mg/L. Hasil penelitian bahwa konsentrasi merkuri (Hg) terdapat pada air sungai dan laut hasilnya sudah melebihi standar baku mutu sesuai Keputusan Menteri Kesehatan Republik Indonesia No. 907/MENKES/SK/VII/2002 yaitu $0,001 \mathrm{mg} / \mathrm{L}$.

Berdasarkan Standar Nasional Indonesia. Dengan demikian dapat dikatakan bahwa mutu air sungai Kobok dan Taolas di perairan Teluk Kao Halmahera Utara sudah tidak bisa dikonsumsi sesuai Peraturan Pemerintah Pengelolaan air minum secara konvensional(kelas 1), 0,001 ppm, (kelas 2 dan 3), 0,002 ppm dan (kelas 4). 0,005 ppm.

Parameter yang mempengaruhi konsentrasi logam berat di perairan adalah suhu, salinitas, arus, $\mathrm{pH}$ dan padatan tersuspensi total atau seston Nanty, (1999). Dengan sendirinya interaksi dari faktor-faktor tersebut akan berpengaruh terhadap fluktuasi konsentrasi logam berat dalam air, karena sebagian logam berat tersebut akan masuk ke dalam sedimen.

\subsection{Kandungan Merkuri (Hg) Pada Sedimen}

Berdasarkan hasil analisis sedimen di perairan Teluk Kao yang didapat berupa lumpur berpasir mendapatkan nilai kandungan merkuri (Hg) sungai Kobok dan Taolas untuk pagi dengan nilai sedimen sebesar $0,0032, \mathrm{mg} / \mathrm{L}$ dan sore nilai sedimen sebesar 0,0076 .

Hasil analisis nilai sedimen di perairan Teluk Kao mendapatkan adanya pembuangan limbah tambang yang diduga menggunakan bahan kimia merkuri $\mathrm{Hg}$ dari PT. Nusa Halmahera Minirals (NHM) dan PETI berpotensi mensuplai merkuri (Hg) pada sedimen. Hasil analisis kandungan merkuri $\mathrm{Hg}$ pada sedimen di perairan Teluk Kao Halmahera utara sudah tidak memenuhi Standar Mutu Bahan Baku Mutu sesuai dengan Peraturan Pemerintah No. 82 Tahun 2001 kelas I. 0,001 mg/L kelas II. 0,002 mg/L kelas III. 0,002 $\mathrm{mg} / \mathrm{L}$ kelas IV 0,005 mg/L.

Menurut Dahuri. Dkk, (2001) bahwa perairan yang sedimentasinya tinggi dapat membahayakan kehidupan di lingkungan perairan, diantaranya sedimen menyebabkan peningkatan kekeruhan air dengan menghalangi penetrasi cahaya yang masuk ke dalam air sehingga dapat mengganggu kehidupan organisme di dalamnya. Sedimen merupakan tempat proses akumulasi logam berat di sekitar perairan laut.

\subsection{Kandungan Merkuri (Hg) di Perairan Teluk Kao}

Perairan Teluk Kao diduga sangat rentan terhadap pencemaran logam berat merkuri yang berasal dari kegiatan penambangan emas yang terdapat di sekitar perairan tersebut (Beringin, Balisosang, dan Dum-dum). Jika hal ini terbukti, maka kelimpahan ikan akan berkurang dan akhirnya dapat mengancam mata pencaharian nelayan yang beroperasi di perairan Teluk Kao. Perairan yang kandungan logam beratnya telah melampaui batas ambang (threshold) yang diperbolehkan dapat menyebabkan kematian masal bagi ikan seperti halnya pada berbagai kasus di perairann Indonesia. Penambangan emas di sekitar perairan Teluk Kao dilakukan sejak tahun 1998 dalam skala besar oleh perusahaan multinasional, yaitu PT. NHM dan PETI. PT. NHM melakukan ekstrasi emas dengan logam berat merkuri (Hg). Dengan minimnya pengolahan limbah yang dilakukan oleh kedua perusahaan tersebut, maka berbagai lembaga swadaya masyarakat (LSM) telah mulai mempertanyakan kualitas perairan Teluk Kao. Kekhawatiran ini sangat beralasan karena sungai-sungai yang mengalir melewati kedua lokasi penambangan semuanya bermuara ke Teluk Kao. Dengan demikian, limbah berupa (Hg) yang digunakan untuk mengekstrak emas pada akhirnya akan bermuara ke perairan Teluk Kao. 
Penelitian tentang kandungan logam berat merkuri (Hg) pernah dilakukan oleh Edward (2008). Penelitian ini diharapkan dapat memberikan informasi tentang kandungan merkuri (Hg) di perairan Teluk Kao. Berdasarkan hasil penelitian ini ternyata kandungan merkuri (Hg) terdapat di air sungai, air laut dan sedimen pasir sudah melebihi nilai ambang batas. Hasil penelitian ini apabila penambangan emas dan perak di daerah ini berjalan terus tanpa pengolahan (penanganan) limbah yang baik, maka bukan tidak mungkin kandungan merkuri (Hg) di perairan Teluk Kao akan terus meningkat dan terakumulasi hingga melebihi nilai ambang batas.

\section{PENUTUP}

4.1. Kesimpulan

Kandungan merkuri (Hg) air sungai, air laut dan sedimen di perairan Teluk Kao dengan jumlah nilai untuk pagi $0,004 \mathrm{mg} / \mathrm{L}$, sedangkan sore sebesar 0,0038 mg/L. Konsentrasi merkuri (Hg) terdapat pada air sudah melebih nilai abang batas standar baku mutu sesuai Standar Nasional Indonesia (SNI 7387:2009) Batas Baksimum Cemaran Logam Berat Dalam Pangan untuk air minirals alami yaitu 0,001 $\mathrm{mg} / \mathrm{L}$, dengan demikian dapat dikatakan bahwa mutu air sungai Kobok dan Taolas di perairan Teluk sudah tidak aman lagi untuk di konsumsi bagi masyarakat Teluk Kao. Sedangkan merkuri (Hg) untuk sedimen dengan nilai untuk pagi yaitu $0,0032 \mathrm{mg} / \mathrm{L}$, dan sore dengan nilai sedimen $0,0076 \mathrm{mg} / \mathrm{L}$. Hasil analisis kandungan merkuri ( $\mathrm{Hg})$ sedimen di perairan Teluk Kao Halmahera utara sudah tidak lagi memenuhi Standar Mutu Bahan Baku Mutu sesuai dengan Peraturan Pemerintah No. 82 Tahun 2001 kelas I. 0,001 mg/L kelas II. 0,002 $\mathrm{mg} / \mathrm{L}$ kelas III. 0,002 mg/L kelas IV 0,005 mg/L.

\subsection{Saran}

Berdasarkan hasil diperoleh dalam penelitian ini, maka perlu disarankan beberapa hal berikut:

1. Perlu dilakukan penelitian logam berat $\mathrm{Pb}$, Seanida pada satu tahun penuh, untuk mendapatkan gambaran yang lebih lengkap tentang pencemaran ketiga jenis logam berat di Perairan Teluk Kao, mulai hulu sungai hingga hilir, sehingga dapat menduga secara tepat sumber pencemaran logam berat berasal.

2. Pemerintah daerah Halmahera Utara dalam hal ini Dinas terkait bertindak cepat melakukan koordinasi antara Pemerintah Provinsi, termasuk dengan pihak PT. NHM, PETI, LSM dan masyarakat agar duduk berasama mengatur monitoring atau kajian pengelolaan limbah secara baik dan bersifat ramah lingkungan.

\section{Ucapan Terima Kasih}

Penulis mengucapkan terima kasih kepada Fakultas Perikanan dan Ilmu Kelautan, Universitas Brawijaya khususnya Kepala Laboratorium Lingkungan dan Bioteknologi Perairan FPIK-UB, Kepala Laboratorium Perum Jasa Tirta Kota Malang dan Masyarakat nelayan Teluk Kao Halmahera Utara sehingga dapat terselesainya penelitian ini.

\section{DAFTAR PUSTAKA}

Achmad, R. 2006. Kimia Lingkungan. Andi. Yogyakarta.

Badan Lingkungan Hidup. 2012. Kabupaten Halmahera Utara. Komisi Akreditasi Nasional Laboratorium Penguji LP-433-IDN. Manado.

Badan Pusat Statistik. Kabupaten Halmahera Utara. Dalam Angka. 2013.

Darmono, 2001. Lingkungan hidup dan pencemaran. Hubungannya denga toksikologi senyawa logam. Penerbit Universitas Indonesia.145 hal.

Darmono, 2008. Lingkungan hidup dan pencemaran. Hubungannya dengan toksikologi senyawa logam. Penerbit Universitas Indonesia. Halaman 74.

Dahuri, R.J. Rais, S.P. Ginting, dan M.J. Sitepu. 1996. Pengelolaan Wilayah Pesisir dan Lautan Secara Terpadu. PT. Pradnya Paramita, Jakarta.

Dinas Kelautan dan Perikanan Halmahera Utara. 2008-2009. Rencana tata ruang laut, pesisir dan pulau-pulau kecil di Kabupaten Halmahera Utara,Tobelo. 
Edward, November 2008. Pengamatan Kadar Merkuri di Perairan Teluk Kao (Halmahera) dan Perairan Anggai (Pulau Obi) Maluku Utara, Makara Sains Volume 12, No.2, November 2008: 97-101.

Hamid, 2011. Konsentrasi Merkuri Pada Air Laut, Sedimen dan Kerang Darah (Anadara granosa Linn) di Perairan Teluk Kao dan Guraping

Keputusan Menteri Negara Lingkungan Hidup No. KEP 51/MENLH/10/1995 Tentan Baku Mutu Limbah Cair Bagi Kegiatan Industri.

Keputusan Menteri Kesehatan Republik IndonesiaNo.907/MENKES/SK/VII/20 02 Tentang Syarat-Syarat dan Pengawasan Kualitas Air Minum.

Nanty, I. H. 1999. Kandungan Logam Berat Dalam Bahan Air Dan Sedimen Di Muara Way Kambas Dan Way Sekampung. IPB.

Nybakken, J.W. 1992. Biologi Laut. Suatu Pendekatan Ekologis. Terjemahan.PT. Gramedia Pustaka Utama. Jakarta. 549 hal.

Pazstor I., P. Thury, and J. Pulai, 2009. Chemical oxygen demand fractions of municipal wastewater for modelingof wastewater treatment University of Pannonia. Veszprem,

wastewater for modelingof wastewater treatment University
Hungary. Journal Environment. Vol. 6(1) 51-56.ISSN: 1735-1472.

Peraturan Pemerintah Republik Indonesia No. 20 Tahun 1990 Tentang: Pengendalian Pencemaran Air. Jakarta.

Peraturan Pemerintah No. 82 Tahun 2001 Tanggal 14 Desember 2001 TentangPengelolaan Kualitas Air dan Pengendalian Pencemaran Air.

Rahman, A. 2006. Kandungan Logam Berat Timbal (Pb) dan Kadmium (Cd) pada Beberapa Jenis Krustasea Di Pantai Batakan dan Takisung Kabupaten Tanah Laut. Kalimantan Selatan. Bioscientiae. Vol. 3, No. 2, Halaman 93-101.

Salmin. 2005. Oksigen Terlarut (DO) dan Kebutuhan Oksigen Biologi (BOD) Sebagai Salah Satu Indikator Untuk Menentukan Kualitas Perairan. Oseana Volume XXX No. 3, 2005, hlm. 1-6.

SNI Standar Nasional Insonesia. 7387 2009. Batas Maksimum Cemaran Logam Berat

Dalam Pangan.

SNI Standar Nasional Indonesia. 06-2412-1991 Metode pengambilan contoh kualitas air.

SNI Standar Nasional Indonesia SNI 6989. 57. 2008. Air dan air limbah Bagian 57:Metoda pengambilan contoh air permukaan.

UNESCO/WHO/UNEP, 1992. Water Quality Assessment. Edited by Chapman,D. Chapman and Hall Ltd. London. 585 p. 